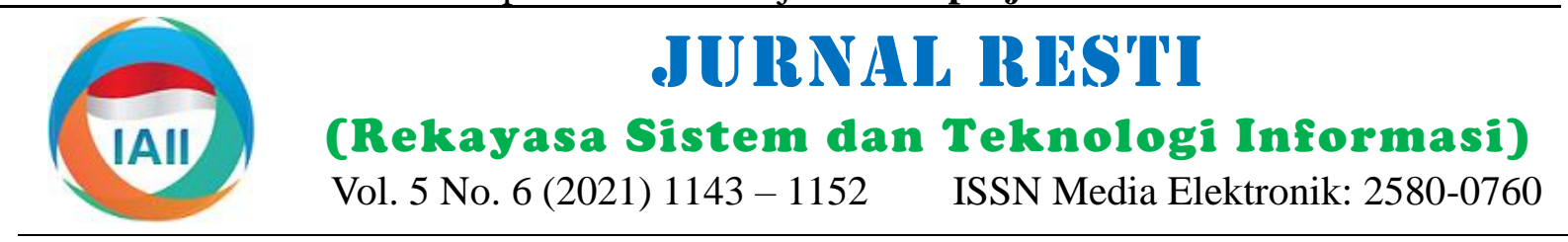

\title{
Perbandingan Metode CBR dan Dempster-Shafer pada Sistem Pakar Terintegrasi Layanan Kesehatan
}

\author{
Istiadi $^{1}$, Emma Budi Sulistiarini ${ }^{2}$, Rudy Joegijantoro ${ }^{3}$, Affi Nizar Suksmawati ${ }^{4}$ \\ ${ }^{1}$ Program Studi Teknik Informatika, Universitas Widyagama Malang \\ ${ }^{2}$ Program Studi Teknik Industri, Universitas Widyagama Malang \\ ${ }^{3}$ Program Studi Kesehatan Lingkungan, STIKES Widyagama Husada \\ ${ }^{4}$ Program Studi Ilmu Komputer, Universitas Gadjah Mada \\ 1'istiadi@widyagama.ac.id, ${ }^{2}$ emma_budi@widyagama.ac.id, ${ }^{3}$ aziro71@ @mail.com, ${ }^{4}$ affinizar@mail.ugm.ac.id
}

\begin{abstract}
Infectious disease is a very dangerous disease with a high mortality rate. Delays in handling the spread of an infectious disease can be minimized using an expert system. This study uses an expert system as a disease consulting service that is integrated with the health care system. Integration with the health care system is used for the knowledge acquisition process. The knowledge base on the expert system uses patient medical record data obtained through the health care system. The expert system can diagnose infectious diseases of sore throat (Pharyngitis), diphtheria, dengue fever, Typhoid fever, tuberculosis, and leprosy. The knowledge acquisition process produces 43 symptoms. These symptoms are used to diagnose new cases using Case-Based Reasoning (CBR) and Dempster-Shafer methods. In the CBR method, the similarity measurement process is determined by comparing the K-Nearest Neighbor, Minkowski Distance, and $3 W$-Jaccard similarity measurement methods. The expert system obtains accuracy values for the CBR K-Nearest Neighbor, CBR Minkowski Distance, and CBR $3 W$-Jaccard methods at a threshold of $70 \%$, respectively $65.71 \%, 80 \%$, and $85.71 \%$. The average length of retrieve time required for each similarity method is $0.083 \mathrm{~s}, 0.107 \mathrm{~s}$, and $6.325 \mathrm{~s}$, respectively. While the diagnosis of disease with Dempster-Shafer gets an accuracy value of $88.57 \%$.
\end{abstract}

Keywords: expert system, health care system, infectious disease, Dempster-Shafer, Case Based Reasoning

\begin{abstract}
Abstrak
Penyakit menular merupakan penyakit yang sangat berbahaya dengan angka kematian cukup tinggi. Keterlambatan penanganan akan terjangkitnya suatu penyakit menular dapat diminimalisir menggunakan sistem pakar. Penelitian ini menggunakan sistem pakar sebagai layanan konsultasi penyakit yang diintegrasikan dengan sistem layanan kesehatan. Integrasi dengan sistem layanan kesehatan digunakan untuk proses akuisisi pengetahuan. Knowledge base pada sistem pakar menggunakan data rekam medis pasien yang didapatkan melalui sistem layanan kesehatan. Sistem pakar mampu mendiagnosis penyakit menular radang tenggorokan (Pharyngitis), difteri, demam berdarah, demam thypoid, tuberkulosis, dan kusta. Proses akuisisi pengetahuan menghasilkan 43 gejala. Gejala tersebut digunakan untuk mendiagnosis kasus baru dengan metode Case-Based Reasoning (CBR) dan Dempster-Shafer. Pada metode CBR proses pengukuran similaritas ditentukan dengan membandingkan metode pengukuran similaritas $K$-Nearest Neighbor, Minkowski Distance, dan 3W-Jaccard. Sistem pakar mendapatkan nilai akurasi untuk metode CBR K-Nearest Neighbor, CBR Minkowski Distance, dan CBR 3W-Jaccard pada threshold $\geq 70 \%$, masingmasing $65.71 \%, 80 \%$, dan $85.71 \%$. Rata-rata lama waktu retrieve yang dibutuhkan setiap metode similaritas masing-masing $0.083 \mathrm{~s}, 0.107 \mathrm{~s}$, dan 6.325s sedangkan diagnosis penyakit dengan Dempster-Shafer mendapatkan nilai akurasi sebesar $88.57 \%$.
\end{abstract}

Kata kunci: sistem pakar, sistem layanan kesehatan, penyakit menular, Dempster-Shafer, Case-Based Reasoning

\section{Pendahuluan}

Penyakit menular tergolong sangat berbahaya karena angka kematiannya cukup tinggi [1]. Unsur penyebab penyakit menular terdiri dari kelompok arthropoda (serangga), helminth (cacing), protozoa, fungi (jamur), bakteri, dan virus. Penularan penyakit dapat secara langsung maupun melalui perantara seperti media udara dan air [2]. Proses penularan penyakit juga dapat terjadi karena kegiatan interaksi manusia dengan sekitarnya. Hal tersebut menyebabkan penyakit menular tidak 
hanya membahayakan untuk seseorang, tetapi juga Distance. Metode similaritas Minkowski Distance orang di lingkungan sekitarnya [3]. Berdasarkan data memperoleh nilai akurasi tertinggi mencapai $100 \%$. yang diperoleh dari Dinas Kesehatan Kota Malang, Penelitian Adiba (2020) menerapkan CBR untuk terdapat enam jenis penyakit menular yang menjadi mendiagnosis penyakit kulit [11]. Penelitian ini perhatian khusus [4]. Penyakit menular tersebut terdiri membandingkan metode similaritas yang terdiri dari $K$ dari Radang Tenggorok (Pharyngitis), Difteri, Demam Nearest Neighbor, Minkowski Distance, dan Simple Berdarah, Demam Typhoid, Tuberkulosis, dan Kusta. Matching Coefficient. Hasil perbandingan menunjukkan Beberapa penyakit menular tersebut menempati urutan bahwa metode similaritas Minkowski Distance memiliki teratas berdasarkan banyaknya jumlah kasus. Seringkali akurasi lebih baik. Penelitian Wibisono (2019) kasus jatuhnya korban disebabkan karena keterlambatan menerapkan metode $C B R$ untuk sistem rekomendasi tindakan dan penanganan [5]. Keterlambatan tindakan resep masakan [10]. Penelitian ini membandingkan dapat disebabkan karena ketidaktahuan masyarakat akan metode similaritas yang terdiri dari Jaccard, Dice, $3 W$ terjangkitnya penyakit menular yang berbahaya [3].

Pemanfaatan teknologi komputasi seperti sistem pakar dapat menjadi solusi untuk meminimalisir Jaccard, Sokal\&Sneath1, Sorgenfrei, dan Ochiai. Hasil implementasi menggunakan $3 W$-Jaccard memperoleh nilai similaritas paling tinggi.

keterlambatan tindakan dan penanganan. Sesuai dengan Penelitian-penelitian tersebut mampu untuk konsep sistem pakar yaitu memetakan keahlian manusia mendapatkan nilai threshold diatas $80 \%$, namun basis ke dalam sistem komputer, agar komputer dapat kasus yang ada belum terintegrasi dengan sistem menyelesaikan masalah seperti yang dilakukan oleh layanan kesehatan. Pada saat seorang dokter/pakar telah pakar [6]. Sistem pakar sebagai layanan konsultasi dapat menyelesaikan kasus baru, basis kasus atau knowledge diintegrasikan dengan sistem layanan kesehatan untuk base masih harus diperbaharui secara manual. Pada mendapatkan knowledge base. Knowledge base terdiri penelitian ini akan diterapkan metode CBR dari fakta-fakta seperti gejala, jenis penyakit, maupun menggunakan metode similaritas K-Nearest Neighbor, hubungan antara keduanya [7]. Knowledge base Minkowski Distance, dan 3W-Jaccard. Beberapa metode didapatkan melalui data rekam medis pasien pada sistem similaritas tersebut dibandingkan untuk mendapatkan layanan kesehatan. Tahap preprocessing dilakukan pada nilai akurasi yang paling baik. Seorang pakar ditetapkan data rekam medis pasien yang masih berupa data tidak sebagai case library untuk memberikan bobot pada terstruktur agar menjadi data terstruktur. Tahap tersebut setiap fitur gejala. Penelitian ini juga mencoba bertujuan untuk memperbaharui knowledge base seiring membandingkan CBR dengan Dempster-Shafer pada dengan proses penambahan data rekam medis.

kasus diagnosis penyakit menular.

Teknologi komputasi mampu memberikan solusi dalam Metode Dempster-Shafer mengkombinasikan potongan bentuk persentase angka sesuai dengan metode dan informasi yang terpisah untuk mengkalkulasikan algoritma tertentu [8]. Metode CBR mampu kemungkinan dari suatu kasus berdasarkan nilai bobot mendapatkan solusi dari kasus-kasus yang memiliki atau kepercayaan yang diberikan [15]. Metode kemiripan [9]. CBR mengkalkulasi nilai kemiripan Dempster-Shafer banyak diterapkan pada berbagai jenis (similaritas) antara kasus lama dengan kasus baru. kasus. Beberapa diantaranya penelitan Kanggeraldo dkk Proses kalkulasi nilai kemiripan dapat menggunakan (2018) menggunakan Dempster-Shafer untuk diagnosis beberapa metode seperti KNN (K-Nearest Neighbor), penyakit stroke, hasil pengujian mendapatkan nilai Minkowski Distance, dan 3W-Jaccard [10][11]. Tiap- akurasi sebesar 97\% [16]. Penelitian Hasibuan dkk tiap kasus lama yang ada dalam basis data dicari (2019) menerapkan metode Dempster-Shafer untuk kemiripannya berdasarkan jarak terdekat dengan kasus mendiagnosis penyakit faringitis [17]. Penelitian Aldo baru.

Penelitian yang menggunakan $C B R$ dengan metode similaritas K-Nearest Neighbor diantaranya penelitian Papuangan (2018) menerapkan CBR untuk sistem diagnosis penyakit hepatitis, hasil validasi memberikan tingkat akurasi sebesar 94.29\% [12]. Penelitian Andriani (2020) menggunakan CBR untuk sistem pelayanan di lembaga kesejahteraan anak, hasil pengujian memperoleh tingkat akurasi sebesar $87.5 \%$ [13]. Beberapa penelitian mencoba untuk membandingkan dkk (2019) mendiagnosis hama dan penyakit bawang merah menggunakan metode Dempster-Shafer, nilai akurasi yang dihasilkan sebesar $95 \%$ dengan representasi pengetahuan berupa aturan dan gejala [18]. Penelitian Wijaya dkk (2020) mendiagnosis penyakit kulit menggunakan metode Dempster-Shafer, hasil nilai rata-rata akurasi sistem sebesar 90\% [19]. Penelitian Saragih dkk (2021) menerapkan metode DempsterShafer untuk sistem deteksi gangguan kecemasan Obessesive Compulsive Disorder [20].

metode similaritas yang menghasilkan akurasi paling Penelitian-penelitian tersebut berhasil menerapkan baik. Penelitian Wahyudi (2017) menggunakan CBR metode Dempster-Shafer pada banyak kasus dengan untuk mendiagnosis penyakit jantung [14]. Penelitian ini persentase nilai akurasi diatas 90\%. Berdasarkan hal membandingkan metode similaritas yang terdiri dari $K$ - tersebut, pada penelitian ini akan dibandingkan metode Nearest Neighbor, Minkowski Distance, dan Euclidean CBR dengan metode Dempster-Shafer untuk jenis kasus

DOI: https://doi.org/10.29207/resti.v5i6.3612

Lisensi: Creative Commons Attribution 4.0 International (CC BY 4.0) 
penyakit menular. Penelitian ini menggunakan knowledge base yang sama untuk metode CBR dan metode Dempster-Shafer, yaitu berupa penyakit, gejala dan bobot pada setiap fitur. Knowledge base akan terintegrasi dengan sistem layanan kesehatan, sehingga dapat diperbaharui secara terus-menerus. Pada metode $C B R$ akan dibandingkan tiga metode pengukuran similaritas yang terdiri dari K-Nearest Neighbor, Minkowski Distance, dan 3W-Jaccard.

\section{Metode Penelitian}

Metode penelitian yang digunakan, digambarkan dalam bentuk bagan pada Gambar 1 .

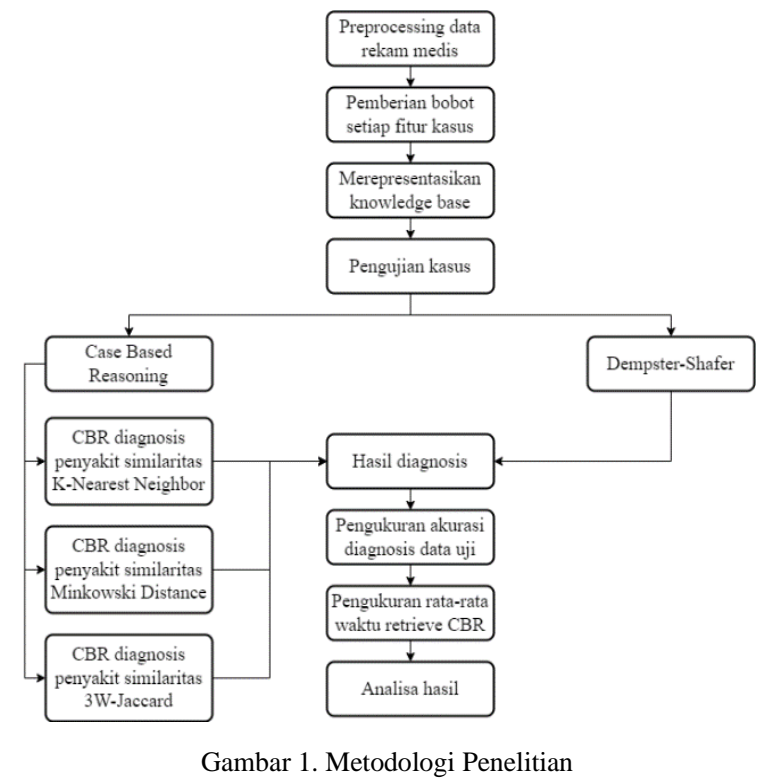

Berdasarkan Gambar 1, tahap awal yang dilakukan adalah preprocessing data rekam medis. Data rekam medis diperoleh dari sistem layanan kesehatan terdiri dari beberapa atribut, yaitu nomor pemeriksaan, nomor rekam medis, tanggal pemeriksaan, nama pasien, jenis kelamin, alamat, dokter, gejala, diagnosis, dan pengobatan. Proses seleksi fitur dilakukan dengan memilih atribut nomor rekam medis, gejala, diagnosis, penambahan atribut kode gejala dan pemberian bobot setiap atribut gejala. Output dari tahap ini adalah data terstruktur yang terdiri dari 6 jenis penyakit, 43 gejala, dan bobot masing-masing gejala. Tahap selanjutnya penyusunan knowledge base yang direpresentasikan dalam bentuk representasi database relasional. Pada repesentasi relasional setiap objek atau kasus direpresentasikan oleh sebuah baris dalam sebuah tabel relasional, dimana kolom digunakan untuk mendefinisikan atribut atau field dari objek [21]. Gambar 2 merupakan representasi knowledge base menggunakan representasi database.

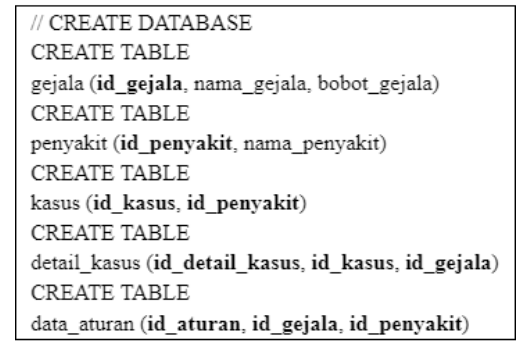

Gambar 2. Representasi struktur Knowledge base menggunakan representasi database.

Pada Gambar 2, Knowledge base direpresentasikan dalam beberapa tabel yang terdiri dari tabel gejala, penyakit, kasus, detail_kasus, dan data_aturan. Setiap tabel memiliki id tabel sebagai primary key dan memiliki relasi id dengan tabel yang lain. Tabel gejala, penyakit, kasus, dan id_kasus digunakan untuk metode $C B R$, sedangkan tabel gejala, penyakit, dan data_aturan digunakan untuk metode Dempster-Shafer. Setelah knowledge base diimplementasikan dalam database dengan konten data penyakit, selanjutnya digunakan dalam aplikasi baik untuk Metode $C B R$ maupun Dempster-Shafer. Alur perhitungan $C B R$ digambarkan dalam bentuk diagram alir Gambar 3.

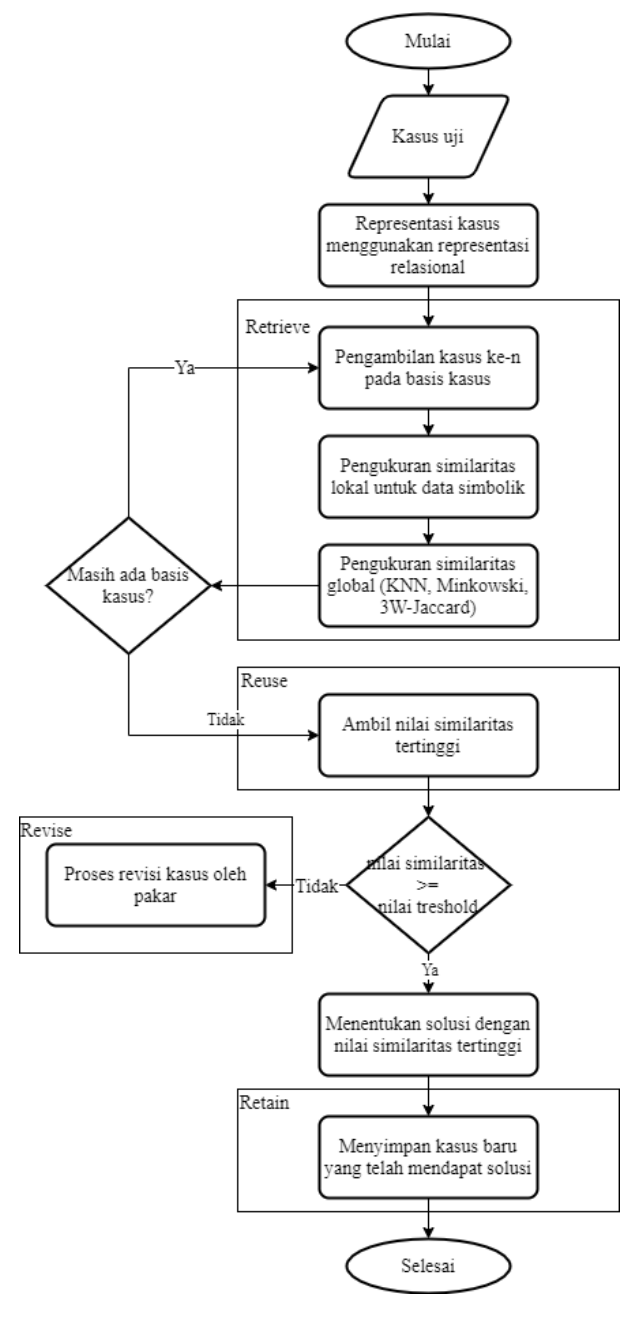

Gambar 3. Flowchart Metode Case Based Reasoning

DOI: https://doi.org/10.29207/resti.v5i6.3612

Lisensi: Creative Commons Attribution 4.0 International (CC BY 4.0) 
Berdasarkan Gambar 3, terdapat empat siklus utama dan Manhattan Distance. Pada Euclidean Distance nilai pada metode $C B R$. Siklus tersebut terdiri dari retrieve pangkat adalah 2 sedangkan pada Manhattan Distance (mencari kasus yang mirip), reuse (menggunakan nilai pangkat adalah 1 [25]. Pada penelitian ini kembali), revise (melakukan penyesuaian atau adaptasi), digunakan Minkowski Distance dengan nilai pangkat 3. dan retain (memperbaharui kasus pada basis kasus). Nilai similaritas global menggunakan Minkowski Siklus $C B R$ diawali dengan proses retrieve, yaitu Distance dapat dihitung menggunakan persamaan 4 mencari kasus lama pada basis kasus yang paling mirip berikut.

dengan kasus baru [22]. Hal ini dilakukan dengan menghitung nilai similaritas kasus baru terhadap tiaptiap kasus lama pada basis kasus. Proses menghitung nilai similaritas menggunakan perhitungan similaritas lokal dan similaritas global. Perhitungan similaritas lokal terdapat pada tingkat fitur. Nilai similaritas berada pada interval 0-1. Nilai 0 menandakan tidak ada kemiripan sama sekali. Nilai 1 menandakan mirip secara identik [23]. Terdapat dua jenis perhitungan similaritas lokal, yaitu untuk data yang bersifat numerik dan data yang bersifat boolean atau kategorikal. Perhitungan similaritas lokal untuk data numerik menggunakan persamaan 1 berikut.

$$
f\left(S_{i}, T_{i}\right)=1-\frac{\left|s_{i}-t_{i}\right|}{\left|f_{\max }-f_{\min }\right|}
$$$$
\operatorname{SimMD}\left(T, S_{i}\right)=\left(\frac{\sum_{i=1}^{n}\left(W_{i}\right)^{r} *\left|f_{i}\left(S_{i}, T_{i}\right)\right|^{r}}{\sum_{i=1}^{n}\left(W_{i}\right)^{r}}\right)^{\frac{1}{r}}
$$

Pada persamaan 4, Simbol $w_{i}$ merupakan nilai bobot yang diberikan oleh pakar pada setiap fitur kasus. Sedangkan simbol $f_{i}\left(S_{i}, T_{i}\right)$ merupakan nilai similaritas lokal. Nilai pangkat $r$ pada Minkowski Distance bernilai 3. Kemudian perhitungan similaritas global diterapkan menggunakan metode $3 W$-Jaccard. Nilai similaritas global menggunakan $3 W$-Jaccard dapat dihitung menggunakan persamaan 5 berikut.

Sim3W-Jaccard $=\frac{3 a}{3 a+b+c}$

(1) Variabel a merupakan nilai bobot yang diberikan oleh pakar dengan mengambil nilai bobot yang memiliki similaritas lokal bernilai 1. Variabel $b$ merupakan nilai Pada persamaan 1, Simbol $S_{i}$ merupakan kasus lama (source), sedangkan $T_{i}$ merupakan kasus baru (target). $f_{\text {max }}$ merupakan nilai maksimal fitur pada basis kasus. Sedangkan $f_{\min }$ merupakan nilai minimal fitur pada basis kasus. Perhitungan similaritas lokal untuk data boolean atau kategorikal menggunakan persamaan 2 berikut.

$$
f\left(S_{i} T_{i}\right)=\left\{\begin{array}{l}
1, \text { jika } S_{i}=T_{i} \\
0, \text { jika } S_{i} \neq T_{i}
\end{array}\right.
$$

Pada persamaan 2, Simbol $S_{i}$ merupakan kasus lama (source), sedangkan $T_{i}$ merupakan kasus baru (target). Nilai similaritas lokal akan bernilai 1, apabila fitur kasus lama sama dengan fitur pada kasus baru. Sebaliknya nilai similaritas lokal 0, apabila fitur kasus lama tidak sama dengan fitur kasus baru. Setelah nilai kemiripan setiap fitur ditentukan, kemudian dilakukan perhitungan nilai similaritas global. Similaritas global merupakan similaritas yang terdapat pada level objek atau terdapat pada kasus. Pada penelitian ini, digunakan metode similaritas global K-Nearest Neighbor, Minkowski Distance, dan $3 W$-Jaccard. Perhitungan nilai similaritas global menggunakan metode $K$-Nearest Neighbor dapat dihitung menggunakan persamaan 3 berikut [24].

$$
\operatorname{SimKNN}\left(T, S_{i}\right)=\frac{\sum_{i=1}^{n} f_{i}\left(S_{i}, T_{i}\right) W_{i}}{\sum_{i=1}^{n} W_{i}}
$$

Pada persamaan 3 , simbol $f_{i}\left(S_{i}, T_{i}\right)$ merupakan nilai similaritas lokal yang dikalikan dengan simbol $w_{i}$ yang merupakan nilai bobot yang diberikan oleh pakar pada setiap fitur kasus. Perhitungan similaritas global juga diterapkan menggunakan metode Minkowski Distance. Minkowski Distance merupakan metode pengukuran metrik dalam ruang vektor yang dapat dianggap sebagai generalisasi dari dua metode, yaitu Euclidean Distance bobot yang memiliki similaritas lokal bernilai 0 sedangkan variabel $c$ merupakan nilai bobot yang fiturnya terdapat pada kasus baru tetapi tidak terdapat pada kasus lama [26]. Siklus selanjutnya pada metode $C B R$ adalah reuse. Pada siklus reuse, kasus-kasus baru yang memiliki nilai kemiripan dengan kasus lama (basis kasus) digunakan kembali untuk mendapatkan solusi dari kasus yang baru. Solusi yang digunakan untuk kasus baru merupakan hasil perhitungan kasus yang mendapatkan nilai similaritas tertinggi. Pada siklus ini juga ditetapkan nilai threshold. Nilai threshold yang ditetapkan pada penelitian ini adalah $\geq 70 \%$. Nilai threshold tersebut digunakan sebagai indikator apakah kasus perlu dilakukan revise oleh pakar atau tidak. Kasus baru yang belum mencapai nilai threshold akan melalui siklus revise oleh pakar.

Pada siklus revise, kasus-kasus yang melalui tahap ini adalah kasus baru yang tidak mendapatkan solusi pada kasus lama (basis kasus). Pada penelitian ini proses revise dilakukan dengan melibatkan pakar untuk mengadaptasikan kasus baru pada kasus lama (basis kasus) melalui user interface sistem pakar. Pakar dapat menambahkan gejala baru dengan memberikan bobot baru beserta solusi dari kasus baru yang belum mendapatkan penyelesaian. Selanjutnya merupakan siklus retain. Pada siklus ini kasus baru yang telah mendapat solusi akan disimpan pada basis data. Kasuskasus baru yang disimpan pada basis data akan menjadi knowledge base untuk kasus baru selanjutnya. Pada penelitian ini hasil perhitungan $C B R$ akan dibandingkan dengan hasil perhitungan Dempster-Shafer. Diagnosis penyakit dengan Dempster-Shafer disajikan pada Gambar 4. 


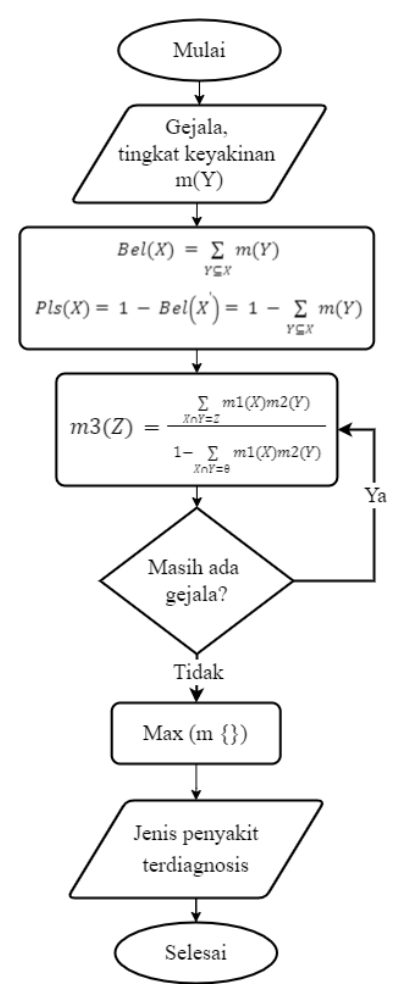

Gambar 4. Flowchart Metode Dempster-Shafer [3]

Berdasarkan Gambar 4, input sistem adalah daftar gejala yang telah dipilih oleh pengguna. Masing-masing gejala tersebut memiliki nilai tingkat kepercayaan (believe) yang telah ditentukan oleh pakar. Kemudian dihitung nilai ketidakpercayaan (plausibility) menggunakan rumus perhitungan plausibility. Tingkat kepercayaan (believe) dinotasikan pada persamaan 6 berikut [27].

$$
\operatorname{Bel}(X)=\sum_{Y \subseteq X} m(Y)
$$

Berdasarkan persamaan 6, simbol $m(Y)$ merupakan nilai kepercayaan gejala penyakit $(Y)$. Sedangkan untuk mencari plausibility digunakan persamaan 7 berikut.

$$
\operatorname{Pls}(X)=1-\operatorname{Bel}\left(X^{\prime}\right)=1-\sum_{Y \subseteq X} m(Y)
$$

Berdasarkan persamaan 7, nilai ketidakpercayaan gejala penyakit (Y) / plausibility didapatkan dari 1 - nilai kepercayaan gejala penyakit (Y). Pada sistem pakar, gejala penyakit yang dipilih oleh pengguna dapat lebih dari 1, sehingga diperlukan perhitungan kombinasi dari setiap gejala yang dipilih oleh pengguna. Perhitungan kombinasi dari beberapa gejala dikenal dengan Dempster's Rule of Combination sesuai dengan persamaan 8 berikut.

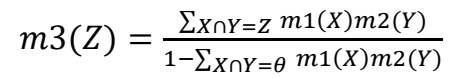

Berdasarkan persamaan $8, m$ merupakan mass function yaitu tingkat kepercayaan dari suatu gejala. Sedangkan $\theta$ merupakan frame of discernment (FOD) yaitu semesta pembicaraan dari sekumpulan jenis penyakit disebut juga dengan environment. Sehingga nilai mass function M3(Z) didapatkan dengan cara menjumlahkan semua irisan $\sum_{X \cap Y} m 1(X) m 2(Y)$ dimana $m 1(X)$ merupakan nilai kepercayaan dari gejala $X$ dikalikan dengan $m 2(Y)$ yang merupakan nilai kepercayaan dari gejala Y. Jumlah nilai kepercayaan gejala $(m)$ tersebut kemudian dibagi dengan jumlah 1 - konflik gejala. Konflik gejala terjadi apabila tidak terdapat irisan pada gejala yang dikombinasikan. Nilai konflik gejala didapatkan dengan mengkalikan nilai kepercayaan dari gejala $m 1(X)$ dengan gejala $m 2(Y)$ yang tidak memiliki irisan.

Apabila semua gejala telah selesai dihitung, selanjutnya akan dilakukan perhitungan nilai maksimal dari mass function yang ada. Mass function dengan nilai maksimal, akan menjadi hasil diagnosis jenis penyakit oleh sistem pakar. Kemudian hasil prediksi menggunakan metode CBR dan Dempster-Shafer akan dievaluasi tingkat akurasinya menggunakan persamaan 9 berikut.

Akurasi $=\frac{\sum_{i=1}^{n} x_{i}}{n} \times 100 \%$

Berdasarkan persamaan 9 , simbol $x_{i}$ merupakan jumlah hasil diagnosis sistem benar, dan $n$ merupakan jumlah data uji. Tingkat akurasi merupakan tingkat kedekatan pengukuran kuantitas terhadap nilai yang sebenarnya. Nilai yang sebenarnya didapatkan dari data pengujian yang telah didiagnosis oleh pakar. Kemudian hasil diagnosis pakar tersebut dibandingkan dengan hasil diagnosis sistem pakar untuk mendapatkan nilai akurasi. Interval nilai akurasi berada pada range $0 \%-100 \%$, maka semakin tinggi nilai akurasi menunjukkan semakin baik pula performa suatu sistem.

\section{Hasil dan Pembahasan}

Implementasi diagnosis penyakit dengan $C B R$ didemonstrasikan pada contoh kasus berikut.

Tabel 1.Representasi Kasus Baru

\begin{tabular}{lll}
\hline No RM & Kode Gejala & \multicolumn{1}{c}{ Nama Gejala } \\
\hline & G7 & Nyeri menelan \\
& G1 & Sakit tenggorokan \\
& G3 & Batuk \\
RM 051 & G11 & Suara serak \\
& G4 & Pilek \\
& G6 & Dinding belakang mulut radang \\
& G2 & Demam \\
& G10 & Sesak napas \\
& Penyakit & $?$ \\
\hline
\end{tabular}

Berdasarkan tabel 1, seorang pengguna/pasien memiliki 8 jenis gejala. Tahap awal untuk mendiagnosis penyakit menggunakan metode $C B R$ adalah proses retrieve, yaitu melakukan perhitungan similaritas lokal dan similaritas global. Karena data memiliki tipe kategorikal, maka perhitungan similaritas lokal dihitung menggunakan persamaan (2). Berikut ini merupakan hasil perhitungan nilai similaritas lokal dan similaritas global yang diimplementasikan pada kasus lama pada basis kasus dengan nomor rekam medis RM024.

DOI: https://doi.org/10.29207/resti.v5i6.3612

Lisensi: Creative Commons Attribution 4.0 International (CC BY 4.0) 
Istiadi, Emma Budi Sulistiarini, Rudy Joegijantoro, Affi Nizar Suksmawati

Jurnal RESTI (Rekayasa Sistem dan Teknologi Informasi) Vol. 5 No. 6 (2021) 1143 - 1152

Tabel 2. Representasi Kasus Baru Pada RM024

Tabel 3. Hasil Similaritas Global Kasus Baru

\begin{tabular}{|c|c|c|c|c|c|c|c|c|c|}
\hline \multirow{2}{*}{$\begin{array}{l}\mathrm{R} \\
\mathrm{M}\end{array}$} & \multirow{2}{*}{ Kode } & \multirow{2}{*}{ Nama Gejala } & \multirow{2}{*}{ Bobot } & \multirow{2}{*}{$\begin{array}{c}\text { SM } \\
\text { Lokal } \\
\end{array}$} & \multirow{3}{*}{ Kode } & \multirow{3}{*}{$\begin{array}{c}\text { Nomer } \\
\text { Basis Kasus }\end{array}$} & \multicolumn{3}{|c|}{ Similaritas Global } \\
\hline & & & & & & & KNN & Minkowski & $3 \mathrm{~W}-$ \\
\hline & G6 & Dinding belakang mulut radang & $90 \%$ & 1 & & & KNIV & & Jaccard \\
\hline & G1 & Sakit tenggorokan & $70 \%$ & 1 & \multirow{14}{*}{$\begin{array}{l}\text { G7, } \\
\text { G1, } \\
\text { G3, } \\
\text { G11, } \\
\text { G4, } \\
\text { G6, } \\
\text { G2, } \\
\text { G10 }\end{array}$} & RM001 & $83,67 \%$ & $96,74 \%$ & $87,86 \%$ \\
\hline & G3 & Batuk & $60 \%$ & 1 & & RM002 & $61,11 \%$ & $81,26 \%$ & $72,26 \%$ \\
\hline $\mathrm{R}$ & G7 & Nyeri menelan & $80 \%$ & 1 & & RM003 & $19,15 \%$ & $53,82 \%$ & $25,47 \%$ \\
\hline M & G2 & Demam & $60 \%$ & 1 & & RM004 & $10,71 \%$ & $49,81 \%$ & $16,07 \%$ \\
\hline 0 & G4 & Pilek & $50 \%$ & 1 & & RM005 & $13,85 \%$ & $43,33 \%$ & $21,77 \%$ \\
\hline 2 & G5 & Tenggorokan terasa kering & $60 \%$ & 0 & & RM006 & $0,00 \%$ & $0,00 \%$ & $0,00 \%$ \\
\hline \multirow[t]{5}{*}{4} & G9 & Mengorok saat bernapas/tidur & $20 \%$ & 0 & & RM007 & $67,50 \%$ & $88,67 \%$ & $69,23 \%$ \\
\hline & \multicolumn{4}{|c|}{ Radang Tenggorokan (Pharyngitis) } & & RM008 & $76,67 \%$ & $96,07 \%$ & $66,99 \%$ \\
\hline & SM & SMGlobal (K-Nearest Neighbor) & \multicolumn{2}{|c|}{0,837} & & RM009 & $42,86 \%$ & $80,37 \%$ & $49,09 \%$ \\
\hline & Glo- & SMGlobal (Minkowski Distance & \multicolumn{2}{|c|}{0,967} & & $\ldots$ & & & $\ldots$ \\
\hline & bal & SMGlobal (3W-Jaccard) & & & & RM061 & $25,00 \%$ & $60,26 \%$ & $32,73 \%$ \\
\hline \multirow{3}{*}{\multicolumn{5}{|c|}{$\begin{array}{l}\text { Pada tabel 2, nilai similaritas lokal } 1 \text { menunjukkan fitur } \\
\text { pada kasus lama sama dengan fitur pada kasus baru. } \\
\text { Nilai similaritas lokal } 0 \text { menunjukkan fitur pada kasus } \\
\text { lama tidak sama dengan fitur pada kasus baru. Setelah }\end{array}$}} & & $\begin{array}{l}\text { Nilai } \\
\text { Maksimum } \\
\text { SM Global }\end{array}$ & $83,67 \%$ & $96,74 \%$ & $87,86 \%$ \\
\hline & & & & & & Diagnosis & RM001 & RM001 & RM001 \\
\hline & & & & & & Penyakit & $\begin{array}{c}\text { (Pharyngi } \\
\text { tis) }\end{array}$ & (Pharyngitis) & $\begin{array}{c}\text { (Pharyngi } \\
\text { tis) }\end{array}$ \\
\hline
\end{tabular}
menghitung nilai similaritas global menggunakan metode K-Nearest Neighbor, Minkowski Distance, dan $3 W$-Jaccard sebagai berikut.

\section{K-Nearest Neighbor}

$(90 \% \times 1)+(70 \% \times 1)+(60 \% \times 1)+(80 \% \times 1)+(60 \% \times 1) p a$

$=\frac{+(50 \% \times 1)+(60 \% \times 0)+(20 \% \times 0)}{90 \%+70 \%+60 \%+80 \%+60 \%+50 \%+60 \%+20 \%}$
$=83,67 \%$

\section{Minkowski Distance}

$=\left[\begin{array}{c}\left(90 \%^{3} \times 1^{3}\right)+\left(70 \%^{3} \times 1^{3}\right)+\left(60 \%{ }^{3} \times 1^{3}\right)+\left(80 \%{ }^{3} \times 1^{3}\right) \\ +\left(60 \%^{3} \times 1^{3}\right)+\left(50 \%^{3} \times 1^{3}\right)+\left(600^{3} \times 0^{3}\right)+\left(20 \%^{3} \times 0^{3}\right) \\ 90 \%^{3}+70 \%^{3}+600^{3}+800^{3}+60 \% 0^{3}+500^{3}+60 \%^{3}+20 \% 3\end{array}\right]^{\frac{1}{3}}$

Pada tabel 3, didapatkan nilai maksimum similaritas global untuk metode K-Nearest Neighbor sebesar 83,67\%, Minkowski Distance sebesar 96,74\%, dan 3WJaccard sebesar $87,86 \%$. Hasil nilai maksimum similaritas global semua metode pengukuran mengarah ) pada diagnosis penyakit Pharyngitis. Pada tabel diatas, nilai maksimum similaritas global setiap metode mencapai lebih dari threshold yang ditetapkan yaitu $\geq$ $70 \%$, maka kasus tersebut dapat dilanjutkan pada siklus retain. Pada siklus retain, kasus baru yang telah mendapat solusi akan disimpan pada basis kasus.

Hasil perhitungan menggunakan metode $C B R$, akan dibandingkan dengan hasil perhitungan menggunakan metode Dempster-shafer. Dempster-Shafer akan menghitung kasus baru pada tabel 1 untuk mendiagnosis jenis penyakit. Tahap awal pada metode DempsterShafer adalah menghitung kombinasi dua gejala awal pada tabel 4 berikut.

$$
\begin{aligned}
& 3 W \text {-Jaccard } \\
& =\frac{3(90 \%+70 \%+60 \%+80 \%+60 \%+50 \%)}{3(90 \%+70 \%+60 \%+80 \%+60 \%+50 \%)} \\
& \quad+(60 \%+20 \%)+(60 \%+30 \%)
\end{aligned}
$$

Berdasarkan perhitungan diatas, nilai similaritas tertinggi pada kasus lama RM 024 adalah menggunakan metode similaritas global Minkowski Distance. Proses perhitungan similaritas global terus dilakukan hingga semua kasus lama pada basis kasus selesai dihitung. Pada penelitian ini data rekam medis yang digunakan sebagai basis kasus berjumlah 61 kasus sedangkan data rekam medis yang digunakan untuk pengujian sebagai kasus baru berjumlah 35 kasus. Total data rekam medis yang digunakan adalah 96 kasus. Setelah semua kasus lama pada basis kasus telah dihitung, tahap selanjutnya adalah siklus reuse. Pada siklus reuse akan didapatkan nilai tertinggi setiap metode pengukuran similaritas global. Berikut ini merupakan hasil pengukuran similaritas global pada kasus baru terhadap seluruh kasus lama pada basis kasus.
Tabel 4.Densitas Awal Kombinasi 1

\begin{tabular}{lllll}
\hline $\begin{array}{l}\text { Mass } \\
\text { Function }\end{array}$ & Gejala & Penyakit & Believe & $\begin{array}{l}\text { Plausi- } \\
\text { bility }\end{array}$ \\
\hline M1 & $\begin{array}{l}\text { Sakit } \\
\text { Tenggorokan }\end{array}$ & $\begin{array}{l}\text { P01, P02 } \\
\text { P01, P02, }\end{array}$ & 0.7 & 0.3 \\
M2 & Demam & $\begin{array}{l}\text { P03, P04, } \\
\text { P05 }\end{array}$ & 0.6 & 0.4 \\
\hline
\end{tabular}

Berdasarkan tabel 4, setiap gejala di simbolkan dengan M1, M2. Mass function M1 memiliki semesta penyakit $\mathrm{P} 01$, dan P02. Sedangkan mass function M2 memiliki semesta penyakit P01, P02, P03, P04, dan P05. Setiap gejala memiliki nilai believe yang merupakan nilai tingkat kepercayaan yang diberikan pakar sedangkan nilai plausibility merupakan nilai ketidakpercayaan yang diperoleh dari hasil perhitungan menggunakan persamaan 7. Kemudian nilai believe dan plausibility mass function M1, dan M2 dikombinasikan menggunakan perhitungan pada tabel 5 . 
Tabel 5. Kombinasi Densitas 1

\begin{tabular}{cll}
\hline & \multicolumn{1}{c}{$\mathrm{M} 2$} & \multicolumn{1}{c}{$\mathrm{M} 2$} \\
& \multicolumn{1}{c}{$(\mathrm{P} 01, \mathrm{P} 02, \mathrm{P} 03, \mathrm{P} 04, \mathrm{P} 05)$} & \multicolumn{1}{c}{$\begin{array}{c}\mathrm{M} \text { (Teta) } \\
0,4\end{array}$} \\
\hline M1 (P01, P02) & $(\mathrm{P} 01, \mathrm{P} 02)$ & $(\mathrm{P} 01, \mathrm{P} 02)$ \\
0,7 & 0,42 & 0,28 \\
M1 (Teta) & (P01, P02, P03, P04, P05) & (Teta) \\
0,3 & 0,18 & 0,12 \\
\hline
\end{tabular}

Pada tabel 5, mass function M1 dengan semesta penyakit P01, P02 dan mass function M2 dengan semesta penyakit $\mathrm{P} 01, \mathrm{P} 02, \mathrm{P} 03, \mathrm{P} 04, \mathrm{P} 05$ memiliki irisan penyakit, yaitu P01, P02. Irisan penyakit P01, P02 akan menjadi mass function selanjutnya, yaitu M3. Nilai irisan penyakit $\mathrm{P} 01, \mathrm{P} 02$ diperoleh dengan mengkalikan nilai M1 $(0,7)$ dengan M2 $(0,6)$. Setelah didapatkan semua nilai irisan, kemudian dilanjutkan dengan menghitung mass function M3 menggunakan persamaan 8 .

$$
\begin{aligned}
& M 3(P 01, P 02)=\frac{0,42+0,28}{1-0}=0,7 \\
& M 3(P 01, P 02, P 03, P 04, P 05)=\frac{0,18}{1-0}=0,18 \\
& M 3(\text { Teta })=\frac{0,12}{1-0}=0,12
\end{aligned}
$$

Berdasarkan perhitungan, didapatkan mass function M3 terdiri dari M3(P01, P02); M3(P01, P02, P03, P04, P05); dan M3 (Teta). Kemudian mass function M3 dikombinasikan dengan mass function yang merupakan gejala selanjutnya pada kasus baru. Berdasarkan tabel 2, gejala selanjutnya adalah gejala batuk sehingga gejala batuk akan menjadi mass function M4. Pada tabel 6 akan

\begin{tabular}{|c|c|c|c|c|}
\hline $\begin{array}{l}\text { Mass } \\
\text { Function }\end{array}$ & Gejala & Penyakit & Believe & $\begin{array}{l}\text { Plausib } \\
\text { ility }\end{array}$ \\
\hline \multirow[t]{2}{*}{ M3 } & & $\mathrm{P} 01, \mathrm{P} 02$ & 0,7 & 0,12 \\
\hline & & $\begin{array}{l}\mathrm{P} 01, \mathrm{P} 02, \mathrm{P} 03, \\
\mathrm{P} 04, \mathrm{P} 05\end{array}$ & 0,18 & \\
\hline M4 & Batuk & $\mathrm{P} 01, \mathrm{P} 02$ & 0,6 & 0,4 \\
\hline
\end{tabular}
diinisialisasikan nilai setiap mass function M3 dan M4.

Tabel 6. Densitas Awal Kombinasi 2

Pada tabel 6, nilai plausibility mass function M3 diperoleh dari nilai semesta penyakit M3 (Teta), yaitu 0.12 dan nilai plausibility mass function M4 diperoleh dari hasil perhitungan persamaan 7. Kemudian nilai believe dan plausibility mass function M3, dan M4 dikombinasikan menggunakan perhitungan pada tabel 7 .

Tabel 7. Kombinasi Densitas 2

\begin{tabular}{cll}
\hline & \multicolumn{1}{c}{ M4 (P01, P02) } & \multicolumn{1}{c}{ M4 (Teta) } \\
0,6 & \multicolumn{1}{c}{0,4} \\
\hline M3 (P01, P02) & $(\mathrm{P} 01, \mathrm{P} 02)$ & $(\mathrm{P} 01, \mathrm{P} 02)$ \\
0,7 & 0,42 & 0,28 \\
M3 (P01, P02, & $(\mathrm{P} 01, \mathrm{P} 02)$ & $(\mathrm{P} 01, \mathrm{P} 02, \mathrm{P} 03$, \\
P03, P04, P05) & & $\mathrm{P} 04, \mathrm{P} 05)$ \\
0,18 & 0,108 & 0,072 \\
M3 (Teta) & (P01, P02) & (Teta) \\
0,12 & 0,072 & 0,048 \\
\hline
\end{tabular}

Pada tabel 7, mass function M3 dengan semesta penyakit P01, P02 dan mass function M4 dengan semesta penyakit P01, P02 memiliki irisan penyakit, yaitu P01, P02. Irisan penyakit P01, P02 akan menjadi mass function selanjutnya, yaitu M5. Kemudian mass function M5 dapat dihitung menggunakan persamaan 8.

$M 5(P 01, P 02)=\frac{0,42+0,108+0,072+0,28}{1-0}=0,88$

$M 5(P 01, P 02, P 03, P 04, P 05)=\frac{0,072}{1-0}=0,072$

$M 5($ Teta $)=\frac{0,048}{1-0}=0,048$

Berdasarkan perhitungan, didapatkan mass function M5 terdiri dari M5(P01, P02); M5(P01, P02, P03, P04, P05); dan M5 (Teta). Kemudian mass function M5 dikombinasikan dengan mass function yang merupakan gejala selanjutnya pada kasus baru. Perhitungan kombinasi setiap mass function terus dilakukan hingga semua gejala yang ada pada kasus baru telah dilakukan perhitungan. Pada tabel 8 akan diinisialisasikan mass function terakhir, yaitu mass function M13 dan M14.

Tabel 8. Densitas Awal Kombinasi 7

\begin{tabular}{lllll}
\hline $\begin{array}{l}\text { Mass } \\
\text { Function }\end{array}$ & Gejala & Penyakit & Believe & Plausibility \\
\hline M13 & & P02 & 0,016 & 0,000944 \\
& & P02, P03, P05 & 0,001 & \\
& & P01 & 0,944 & \\
& & P01, P02 & 0,037 & \\
& & P01, P02, P03, & 0,001 & \\
M14 & P04, P05 & & \\
& Suara & P02 & 0,6 & 0,4 \\
\hline
\end{tabular}

Pada tabel 8, mass function M14 merupakan gejala terakhir pada kasus baru dengan semesta penyakit M14 (P02). Nilai plausibility mass function M13 diperoleh dari nilai semesta penyakit M13 (Teta), yaitu sebesar 0,000944. Nilai plausibility mass function M14 diperoleh dari hasil perhitungan persamaan 7. Kemudian nilai believe dan plausibility mass function M13, dan M14 dikombinasikan menggunakan perhitungan pada tabel 9.

Tabel 9. Kombinasi Densitas 7

\begin{tabular}{cll} 
& \multicolumn{1}{c}{ M14 (P02) } & \multicolumn{1}{c}{ M14 (Teta) } \\
& \multicolumn{1}{c}{0,6} & \multicolumn{1}{c}{0,4} \\
M13 (P02) & $(\mathrm{P} 02)$ & $(\mathrm{P} 02)$ \\
0,0158427 & 0,0095056 & 0,00633708 \\
M13 (P02, P03, P05) & $(\mathrm{P} 02)$ & $(\mathrm{P} 02, \mathrm{P} 03, \mathrm{P} 05)$ \\
0,0010112 & 0,0006067 & 0,00040448 \\
M13 (P01) & Konflik & $(\mathrm{P} 01)$ \\
0,9438202 & 0,5662921 & 0,37752808 \\
M13 (P01, P02) & $(\mathrm{P} 02)$ & $(\mathrm{P} 01, \mathrm{P} 02)$ \\
0,0369663 & 0,0221798 & 0,01478652 \\
M13 (P01, P02, & $(\mathrm{P} 02)$ & $(\mathrm{P} 01, \mathrm{P} 02, \mathrm{P} 03$, \\
P03, P04, P05) & 0,0008494 & 0,00056628 \\
0,0014157 & $(\mathrm{P} 02)$ & $($ Teta $)$ \\
M13 (Teta) & 0,0005663 & 0,00037752 \\
0,0009438 & &
\end{tabular}


Pada tabel 9, mass function M13 dengan semesta dilakukan perbandingan pada penetapan nilai threshold penyakit P01 dan mass function M14 dengan semesta sebesar $\geq 60 \%$, $\geq 70 \%$, dan $\geq 80 \%$ setiap metode penyakit P02 tidak memiliki irisan penyakit. Sehingga similaritas pada data uji. Tabel 10 merupakan hasil kombinasinya adalah konflik. Nilai konflik diperoleh perbandingan nilai akurasi threshold.

dengan mengkalikan nilai M13(0,9438202) dengan M14(0,6). Nilai konflik digunakan untuk menghitung mass function M15 sebagai pembagi pada persamaan 8.

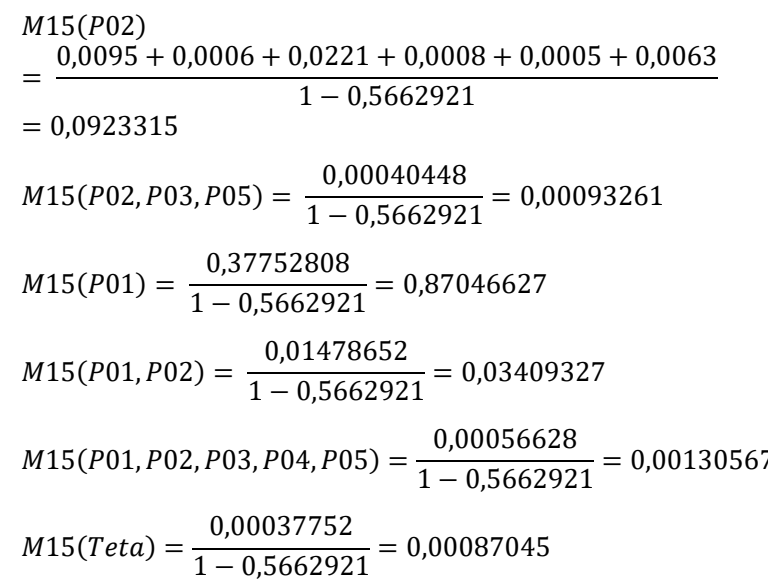

\begin{tabular}{lccc}
\hline Metode Similaritas & $\begin{array}{c}\text { Threshold } \\
\geq 60 \%\end{array}$ & $\begin{array}{c}\text { Threshold } \\
\geq 70 \%\end{array}$ & $\begin{array}{c}\text { Threshold } \\
\geq 80 \%\end{array}$ \\
\hline K-Nearest Neighbor & $71,43 \%$ & $65,71 \%$ & $57,14 \%$ \\
Minkowski Distance & $80,00 \%$ & $80,00 \%$ & $80,00 \%$ \\
3W-Jaccard & $85,71 \%$ & $85,71 \%$ & $65,71 \%$ \\
\hline
\end{tabular}

Pada tabel 10, metode similaritas yang memiliki akurasi tertinggi pada threshold $\geq 60 \%$ dan threshold $\geq 70 \%$ adalah $3 W$-Jaccard. Kemudian pada threshold $\geq 80 \%$ nilai akurasi tertinggi adalah metode similaritas Minkowski Distance. Selain itu nilai akurasi pada metode similaritas Minkowski Distance memiliki perubahan yang tetap atau stabil. Kemudian dihitung lama proses retrieve untuk setiap metode similaritas. Berikut merupakan hasil perhitungan lama waktu proses retrieve pada setiap metode similaritas.

Tabel 11. Lama Waktu Proses Retrieve

Berdasarkan perhitungan akhir, didapatkan mass function M15 dengan nilai tertinggi adalah pada semesta penyakit P01 yaitu sebesar 87,05\%. Sehingga prediksi jenis penyakit untuk kasus baru menggunakan metode Dempster-Shafer adalah penyakit Radang Tenggorok / Pharyngitis. Pada tahap pengujian sistem, metode $C B R$ dan Dempster-Shafer diuji untuk mendiagnosis 35 data rekam medis pasien penyakit menular. Data tersebut sebelumnya telah didiagnosis oleh pakar. Sehingga nilai akurasi sistem didapatkan dengan menghitung jumlah benar hasil yang didiagnosis sistem pakar terhadap hasil diagnosis pakar. Berikut merupakan hasil perhitungan akurasi sistem pakar sebelum diterapkan batas nilai threshold pada metode Case-Based Reasoning.

CBR dengan $K$-Nearest Neighbor

Akurasi $=\frac{27}{35} \times 100 \%=77.14 \%$

CBR dengan Minkowski Distance

Akurasi $=\frac{28}{35} \times 100 \%=80.00 \%$

CBR dengan $3 W$-Jaccard

Akurasi $=\frac{30}{35} \times 100 \%=85.71 \%$

Dempster-Shafer

Akurasi $=\frac{31}{35} \times 100 \%=88.57 \%$

Berdasarkan perhitungan, nilai akurasi tertinggi adalah menggunakan metode Dempster-Shafer sebesar $88.57 \%$, kemudian diikuti oleh metode CBR $3 W$ Jaccard sebesar $85.71 \%$, kemudian metode CBR Minkowski Distance sebesar 80\%, dan metode CBR KNearest Neighbor sebesar $77.14 \%$. Pada metode CBR

\begin{tabular}{lcccccc}
\multicolumn{7}{c}{ Tabel 11. Lama Waktu Proses Retrieve } \\
\hline $\begin{array}{l}\text { Metode } \\
\text { Similaritas }\end{array}$ & $\begin{array}{c}\text { Iterasi } \\
1\end{array}$ & $\begin{array}{c}\text { Iterasi } \\
2\end{array}$ & $\begin{array}{c}\text { Iterasi } \\
3\end{array}$ & $\begin{array}{c}\text { Iterasi } \\
4\end{array}$ & $\begin{array}{c}\text { Iterasi } \\
5\end{array}$ & $\begin{array}{c}\text { Rata- } \\
\text { rata }\end{array}$ \\
\hline $\begin{array}{l}\text { K-Nearest } \\
\text { Neighbor } \\
\text { Minkowski }\end{array}$ & 0,078 & 0,076 & 0,091 & 0,091 & 0,08 & 0,083 \\
$\begin{array}{l}\text { Distance } \\
\text { 3W- }\end{array}$ & 0,113 & 0,113 & 0,104 & 0,098 & 0,105 & 0,107 \\
Jaccard & 6,417 & 6,099 & 6,688 & 6,37 & 6,049 & 6,325 \\
\hline
\end{tabular}

Pada tabel 11, setiap metode similaritas diiterasi sebanyak 5 kali proses retrieve. Sehingga didapatkan waktu rata-rata proses retrieve dalam satuan second. Lama waktu retrieve tercepat adalah metode similaritas K-Nearest Neighbor. Kemudian diikuti oleh metode similaritas Minkowski Distance, dan metode similaritas $3 W$-Jaccard. Lama waktu retrieve digambarkan dalam bentuk grafik pada gambar 5 .

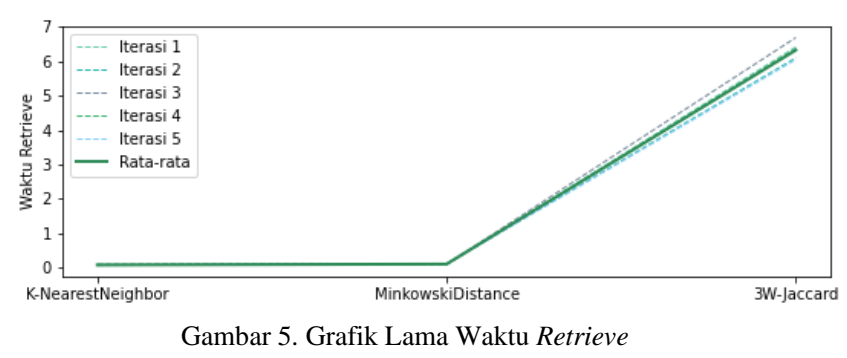

Pada gambar 5, metode similaritas K-Nearest Neighbor dan metode similaritas Minkowski Distance memiliki perbedaan waktu yang tidak terlalu signifikan, namun pada metode similaritas $3 W$-Jaccard grafik lama waktu meningkat secara signifikan.

\section{Kesimpulan}

Kesimpulan yang diperoleh dari penelitian ini yaitu, sistem pakar penyakit menular dapat mendiagnosis penyakit Radang Tenggorokan (Pharyngitis), Difteri,

DOI: https://doi.org/10.29207/resti.v5i6.3612

Lisensi: Creative Commons Attribution 4.0 International (CC BY 4.0) 
Demam Berdarah, Demam Typhoid, Tuberkulosis, dan Kusta. Sistem pakar penyakit menular terintegrasi dengan sistem layanan kesehatan. Proses integrasi bertujuan agar knowledge base pada sistem pakar dapat terus-menerus diperbaharui pada saat proses penambahan data rekam medis pasien pada sistem layanan kesehatan.

Metode CBR dan Dempster-Shafer pada sistem pakar diterapkan untuk mendiagnosis jenis penyakit menular pada kasus baru. Metode pengukuran similaritas pada CBR menggunakan K-Nearest Neighbor, Minkowski Distance, dan 3W-Jaccard. Hasil akurasi diagnosis penyakit menular pada nilai threshold $\geq 70 \%$ menggunakan CBR K-Nearest Neighbor adalah sebesar 65.71\%, CBR Minkowski Distance adalah sebesar 80\%, CBR 3W-Jaccard adalah sebesar $85.71 \%$, dan menggunakan metode Dempster-Shafer sebesar $88.57 \%$. Sedangkan rata-rata lama waktu proses retrieve pada metode CBR K-Nearest Neighbor sebesar 0.083 second, CBR Minkowski Distance sebesar 0.107 second, dan CBR 3W-Jaccard sebesar 6,325 second. Pertimbangan kompleksitas perhitungan setiap metode similaritas juga mempengaruhi lama waktu proses retrieve.

Menggunakan metode $C B R$ dengan metode similaritas $3 W$-Jaccard memiliki nilai akurasi paling tinggi, namun cenderung tidak stabil pada threshold $\geq 70 \%$, dan $\geq$ $80 \%$. Selain itu metode $3 W$-Jaccard memiliki waktu retrieve yang paling lama sedangkan metode similaritas Minkowski Distance cenderung stabil pada threshold $\geq$ $60 \%, \geq 70 \%$, dan $\geq 80 \%$ dan memiliki waktu retrieve yang jauh lebih cepat dari metode similaritas $3 W$ Jaccard. Kemudian metode similaritas K-Nearest Neighbor memiliki nilai akurasi paling rendah pada threshold $\geq 60 \%, \geq 70 \%$, dan $\geq 80 \%$, namun memiliki waktu retrieve yang paling cepat.

Pada penelitian ini masih belum diterapkan metode indexing pada proses retrieve metode $C B R$ yang dapat mempercepat lama waktu proses retrieve. Selain itu juga belum diterapkan pengukuran tingkat keyakinan pakar terhadap permasalahan kasus baru yang dapat meningkatkan nilai akurasi diagnosis. Kekurangan pada penelitian ini dapat di perbaiki pada penelitian yang selanjutnya.

\section{Ucapan Terimakasih}

Penelitian ini didukung oleh Kementerian Pendidikan, Kebudayaan, Riset, dan Teknologi melalui hibah penelitian tahun 2021.

\section{Daftar Rujukan}

[1] A. Darmawan, "Pedoman Epidemiologi Penyakit Menular dan Tidak Menular," Jmj, vol. 4, no. 2, pp. 195-202, 2016, doi: https://doi.org/10.22437/jmj.v4i2.3593.

[2] I. Dharmayanti and D. H. Tjandararini, "Identifikasi Indikator [18] dalam Indeks Pembangunan Kesehatan Masyarakat (IPKM) untuk Meningkatkan Nilai Sub-Indeks Penyakit Menular,' $J$. Keperawatan Padjadjaran, vol. 5, no. 3, pp. 249-257, Jan. 2018, doi: 10.24198/jkp.v5i3.647.

[3] I. Istiadi, Emma Budi Sulistiarini, Rudy Joegijantoro, and Dedi Usman Effendy, "Infectious Disease Expert System Using Dempster-Shafers With Recommendations for Health Services," J. RESTI (Rekayasa Sist. dan Teknol. Informasi), vol. 4, no. 1, pp. 17-27, Feb. 2020, doi: 10.29207/resti.v4i1.1332.

[4] Dinas Kesehatan Kota Malang, Profil Kesehatan Kota Malang. Malang, 2019.

[5] Istiadi, D. U. Effendy, E. B. Sulistiarini, and R. Joegijantoro, "Expert System for Mobile Consulting Services with Position Detection," 2nd Int. Conf. Informatics Dev., no. November, pp. 1-5, 2018, [Online]. Available: http://icid.sunankalijaga.org/article/read_paper.php?id=40.

[6] Istiadi and E. B. Sulistiarini, "Representing Knowledge base into Database for WAP and Web-based Expert System," no. April 2014, pp. 81-85, 2013, [Online]. Available: http://eprints.undip.ac.id/41698/.

7] S. Rustam, H. A. Santoso, and C. Supriyanto, "OPTIMASI KMEANS CLUSTERING UNTUK IDENTIFIKASI DAERAH ENDEMIK PENYAKIT MENULAR DENGAN ALGORITMA PARTICLE SWARM OPTIMIZATION DI KOTA SEMARANG," Ilk. J. Ilm., vol. 10, no. 3, pp. 251-259, Dec. 2018, doi: 10.33096/ilkom.v10i3.342.251-259.

[8] S. Rustam, H. A. Santoso, and C. Supriyanto, "Optimasi KMeans Clustering Untuk Identifikasi Daerah Endemik Penyakit Menular Dengan Algoritma Particle Swarm Optimization Di Kota Semarang," Ilk. J. Ilm., vol. 10, no. 3, pp. 251-259, 2018, doi: 10.33096/ilkom.v10i3.342.251-259.

[9] T. Rismawan and S. Hartati, "Case-Based Reasoning untuk Diagnosis Penyakit THT (Telinga Hidung dan Tenggorokan)," IJCCS (Indonesian J. Comput. Cybern. Syst., vol. 7, no. 1, pp. 67-78, Jul. 2013, doi: 10.22146/ijccs.2154.

10] S. Wibisono, W. Hadikurniawati, and M. S. Utomo, "Studi Kinerja Algoritma Similaritas berbobot dalam Case Based Reasoning Rekomendasi Resep Kuliner Indonesia," Proceeding SINTAK 2019, pp. 389-397, 2019, [Online]. Available: https://unisbank.ac.id/ojs/index.php/sintak/article/view/7618.

[11] F. Adiba, N. M. Abdal, and A. A. N. Risal, "Diagnosis Penyakit Kulit Menggunakan Case Based-Reasoning dan Self Organizing Maps," Indones. J. Fundam. Sci., vol. 6, no. 1, p. 53, Apr. 2020, doi: 10.26858/ijfs.v6i1.13967.

[12] M. Papuangan, "Penerapan Case Based Reasoning Untuk Sistem Diagnosis Penyakit Hepatitis," JIKO (Jurnal Inform. dan Komputer), vol. 1, no. 1, pp. 7-12, 2018, doi: 10.33387/jiko.v1i1.1165.

[13] P. Gigih, C. Andriani, I. Istiadi, and M. H. Abd Wahab, "Case Service System at the Child Welfare Institution using the CaseBased Reasoning Method," Int. J. Electr. Energy Power Syst. Eng., vol. 3, no. 2, pp. 40-45, 2020, doi: 10.31258/ijeepse.3.2.40-45.

[14] E. Wahyudi and S. Hartati, "Case-Based Reasoning untuk Diagnosis Penyakit Jantung," IJCCS (Indonesian J. Comput. Cybern. Syst., vol. 11, no. 1, p. 1, 2017, doi: 10.22146/ijccs. 15523 .

[15] E. Lestari and E. U. Artha, "Sistem Pakar dengan Metode Dempster-Shafer untuk Diagnosis Gangguan Layanan INDIHOME di PT TELKOM Magelang," Khazanah Inform. J. Ilmu Komput. dan Inform., vol. 3, no. 1, p. 16, Jul. 2017, doi: 10.23917/khif.v3i1.3342

[16] J. Kanggeraldo, R. P. Sari, and M. I. Zul, "Sistem Pakar Untuk Mendiagnosis Penyakit Stroke Hemoragik dan Iskemik Menggunakan Metode Dempster-Shafer," J. RESTI (Rekayasa Sist. dan Teknol. Informasi), vol. 2, no. 2, pp. 498-505, 2018, doi: 10.29207/resti.v2i2.268.

[17] P. S. Hasibuan and M. I. Batubara, "Penerapan Metode Dempster-Shafer Dalam Mendiagnosis Penyakit Faringitis," $J$. Media Inform. Budidarma, vol. 3, no. 1, p. 59, 2019, doi: 10.30865/mib.v3i1.1061.

[18] D. Aldo, "Sistem Pakar Diagnosis Hama Dan Penyakit Bawang Merah Menggunakan Metode Dempster-Shafer," Komputika J. 
Sist. Komput., vol. 9, no. 2, pp. 85-93, 2020, doi: 10.34010/komputika.v9i2.2884.

[19] A. R. MZ, I. G. P. S. Wijaya, and F. Bimantoro, "Sistem Pakar Diagnosis Penyakit Kulit pada Manusia dengan Metode Dempster-Shafer," J. Comput. Sci. Informatics Eng., vol. 4, no. 2, pp. 129-138, 2020, doi: 10.29303/jcosine.v4i2.285.

[20] N. Saragih, R. A.-J. MEDIA, and undefined 2021, "Penerapan Metode Dempster-Shafer Untuk Sistem Deteksi Gangguan Kecemasan Obsessive Compulsive Disorder Berbasis Web," Ejurnal.Stmik-Budidarma.Ac.Id, vol. 5, no. 1, pp. 48-57, 2021, doi: $10.30865 / \mathrm{mib} . v 5 i 1.2533$.

[21] S. K. Pal and S. C. K. Shiu, Foundations of Soft Case-Based Reasoning. John Wiley \& Sons, 2004.

[22] A. Setiawan et al., "Case Based Reasoning Menggunakan Algoritma K-Nearest Neighbors Untuk Penanganan Penyakit Ikan Cupang Hias," SCAN-Jurnal Teknol. Inf. dan Komun., vol. $\mathrm{XV}, \quad$ pp. 1-5, 2020, [Online]. Available: http://www.ejournal.upnjatim.ac.id/index.php/scan/article/vie w/2082.

[23] M. Papuangan and M. Salmin, "Penggunaan Algoritma Nearest Neighbor Pada Sistem Penalaran Berbasis Kasus Untuk
Diagnosis Penyakit ISPA," J. Serambi Eng., vol. 5, no. 1, 2020, doi: $10.32672 /$ jse.v5i1.1739.

[24] I. Nugraha and M. Siddik, "Penerapan Metode Case Based Reasoning ( CBR ) Dalam Sistem Pakar Untuk Menentukan Diagnosis Penyakit Pada Tanaman Hidroponik," J. Mhs. Apl. Teknol. Komput. dan Inf., vol. 2, no. 2, pp. 91-96, 2020, [Online]. Available: http://www.ejournal.pelitaindonesia.ac.id/JMApTeKsi/index.p $\mathrm{hp} / \mathrm{JOM} / \mathrm{article} / \mathrm{view} / 575$.

[25] M. Salmin and S. Hartati, "Case Based Reasoning untuk Diagnosis Penyakit Infeksi Saluran Pernapasan Akut," JIKO (Jurnal Inform. dan Komputer), vol. 1, no. 1, pp. 21-26, 2018, doi: 10.33387/jiko.v1i1.1167.

[26] A. Dewandono and W. Hadikurniawati, "Case-Based Reasoning Diagnosis Kerusakan Mesin Pada Mobil Menggunakan AlgoritmA 3W-Jaccard," J. Mahajana Inf., vol. 6, no. 1, pp. 1-9, 2021, doi: https://doi.org/10.51544/jurnal\%20mi.v6i1.1982.

[27] Joseph C. Giarratano dan Gary Riley, "Expert Systems, Principles and Programming. Course Technology," vol. 27, no. 3, pp. 585-586, 2005. 